\title{
Irrigation Practices for Peaches in Florida'
}

\author{
C. Zambrano-Vaca, L. Zotarelli, K. Migliaccio, R. Beeson Jr., K. Morgan, J. Chaparro, and M. \\ Olmstead $^{2}$
}

\section{Introduction}

This document provides basic information and guidelines on water requirements and irrigation strategies for peaches (Prunus persica L.) grown in Florida (Figure 1). Several considerations should be made when irrigation is planned for peach production, such as cultivar selection, type of irrigation system, and freeze protection. Irrigation management requires knowledge of soil properties, phenological stages of the plant, rainfall amounts throughout the year, and reference evapotranspiration (ETo).

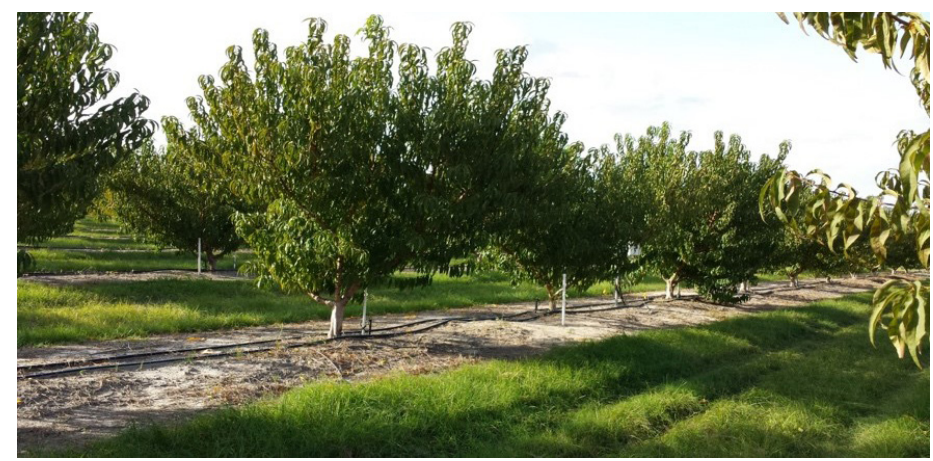

Figure 1. Peach trees in a commercial orchard in central Florida. Credits: Carlos Zambrano-Vaca, UF/IFAS

Because of variations of weather and soil conditions, site-specific irrigation scheduling may contribute to a reduction in pumping costs and/or losses of agrochemicals. Information about soil characteristics, weather conditions, phenological stage of the plant (i.e. flowering, dormancy), irrigation system efficiency, irrigation application uniformity, and ETo are required to develop an irrigation schedule. Irrigation scheduling determines how often and how much water to irrigate by providing an accurate irrigation volume to meet the water requirements of the crop. Further adjustments on the irrigation schedule are necessary based on changes in crop evapotranspiration (ETc).

Proper irrigation management is essential for providing adequate soil water availability in the root zone and to optimize fruit growth and yield. During the final growth phase, peaches accumulate $80 \%$ of a fruit's fresh weight (Chalmers and Wilson 1978); therefore, avoiding water stress during fruit growth is essential to obtain high yields. Over-irrigation is the application of water in excess of the soil water holding capacity, resulting in water movement out of the root zone nutrients. Conversely, under-irrigation can lead to plant water stress that directly impacts peach fruit size, quality, and marketable yield.

\section{Cultivar Variability and Chilling Hour Requirement}

The cultivar selection and chilling requirements may affect the duration of phenological stages and, thus, plant water needs. Cultivar selection also influences the need for freeze protection. Historical chilling hour accumulation in Florida (Figure 2) can help determine the most suitable cultivar

1. This document is HS1316, one of a series of the Horticultural Sciences Department, UF/IFAS Extension. Original publication date April 2018. Visit the EDIS website at http://edis.ifas.ufl.edu.

2. C. Zambrano-Vaca, graduate student, Horticultural Sciences Department; L. Zotarelli, associate professor, Horticultural Sciences Department; K. Migliaccio, professor, Department of Agricultural and Biological Engineering; R. Beeson Jr., associate professor, Department of Environmental Horticulture; K. Morgan, professor, Department of Soil and Water Sciences; J. Chaparro, associate professor, Horticultural Sciences Department; and M. Olmstead, former associate professor, Horticultural Sciences Department; UF/IFAS Extension, Gainesville, FL 32611. 
for a location. There are several low-chill peach varieties available on the market than can be successfully produced in the Florida climate. A detailed list of varieties suitable for Florida is provided in Olmstead et al. (2016). Additionally, the accumulated chilling hours during the winter can be monitored using the AgroClimate tool available at: http:// agroclimate.org/tools/Chill-Hours-Calculator/ (Agroclimate 2017).

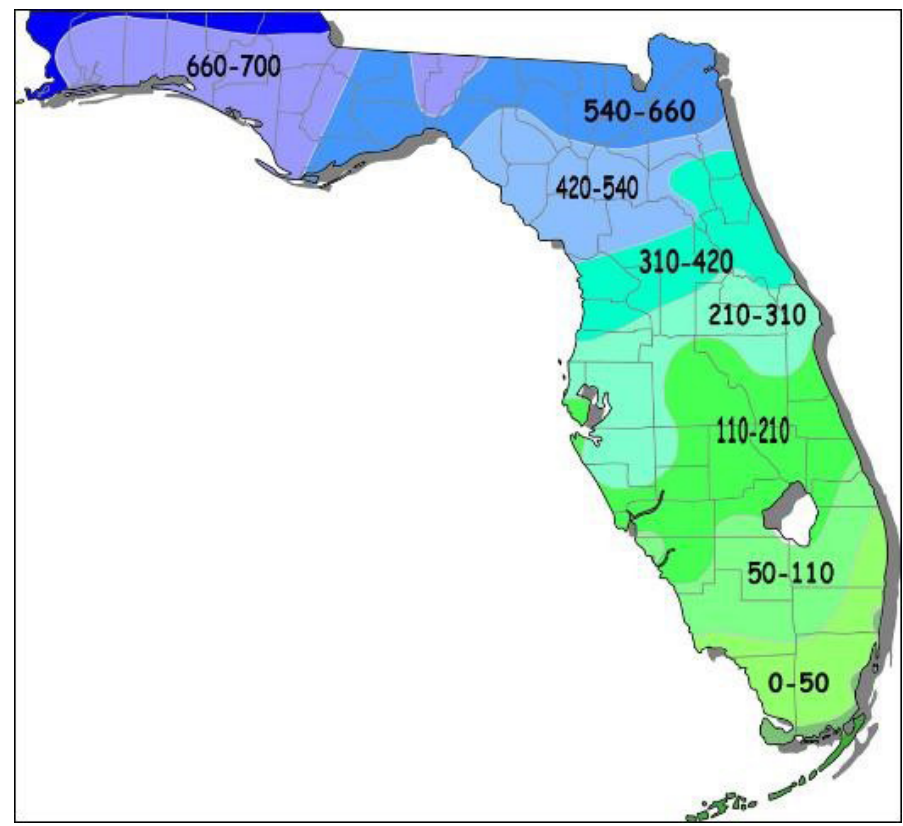

Figure 2. Historical chilling hour accumulation in the state of Florida. Credits: http://gardeningsolutions.ifas.ufl.edu/plants/edibles/fruits/ chill-hours.html

\section{Irrigation Systems for Peaches}

Peach trees in Florida are irrigated using micro-sprinklers, usually one emitter per tree. Several micro-sprinklers with different flow rates and irrigation coverage are available in the market (Figure 3). As a general rule, the microsprinkler should cover $50 \%$ or more of the area under the tree canopy. However, up to $80 \%$ irrigation efficiency can be achieved by a well-maintained and managed microsprinkler irrigation system (Haman et al. 2005). Growers in Florida commonly irrigate early in the morning to reduce losses due to evaporation or wind, with two or three irrigation events per week. Micro-sprinklers are also used for freeze protection, which has become a common practice for many growers as an alternative to the traditional overhead high-volume sprinklers that growers have to remove for pruning (Figure 4).
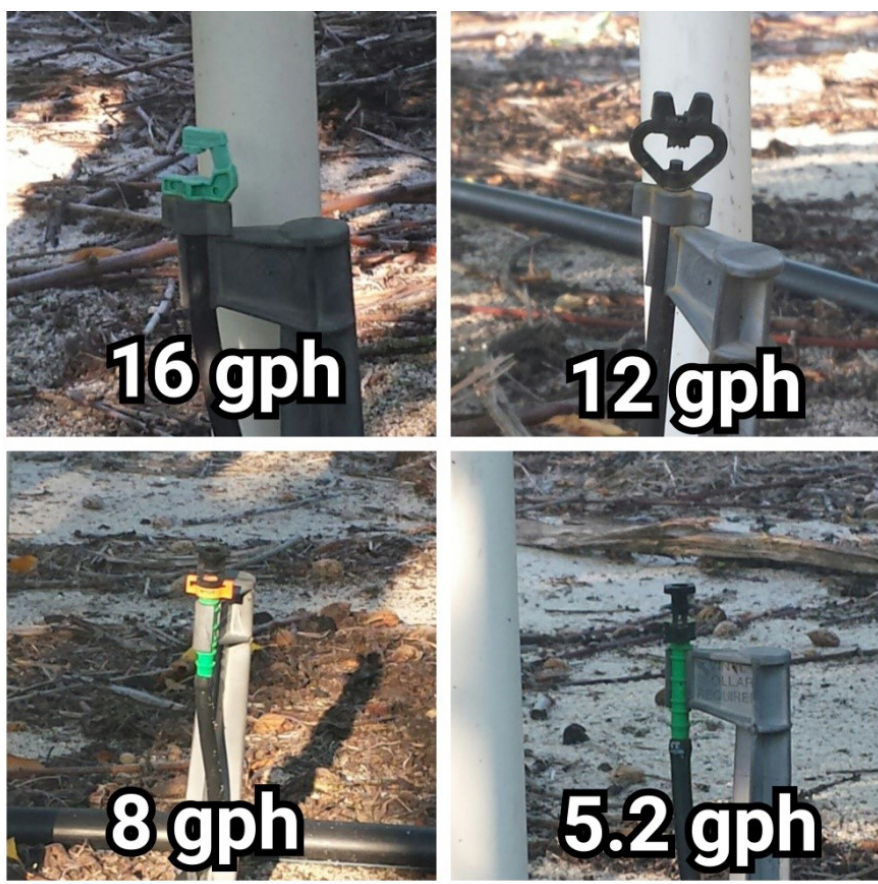

Figure 3. Examples of micro-sprinkler heads used for irrigation in peaches.

Credits: Carlos Zambrano-Vaca, UF/IFAS

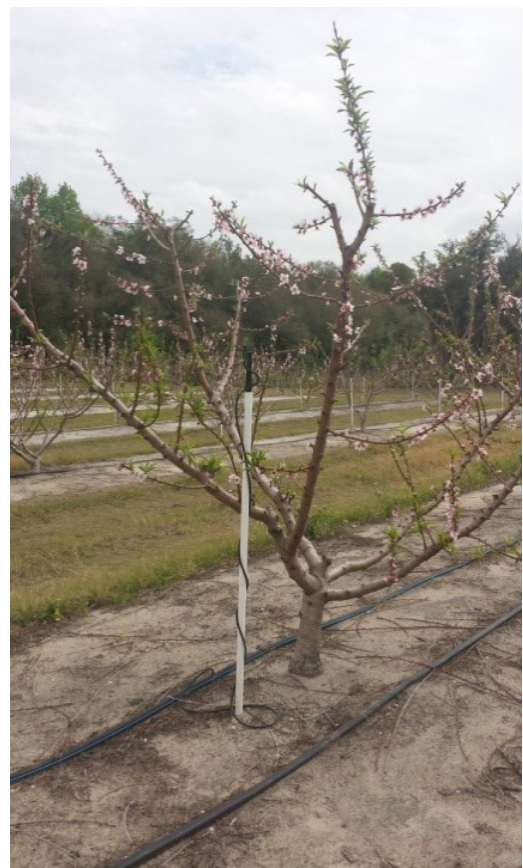

Figure 4. Micro-sprinkler irrigation system used for water supply and freeze protection.

Credits: Carlos Zambrano-Vaca, UF/IFAS

\section{Peach Phenological Stages and Water Needs}

Irrigation in peaches should be adjusted due to changes in ETo and demand of phenological stage of the tree. The peach tree phenological stages include flowering and fruit growth, vegetative growth, and dormancy. Reduced irrigation volumes can be safely used depending on the 
phenological stage without affecting fruit or plant growth. Depending on the month of the year, different percentages of soil water depletion are recommended. Soil water depletion is defined as the amount of soil-available water that has been removed from the root zone (an example of soil water depletion calculation is given below). In practical ways, irrigation for peaches can be divided in the three crop phases or stages. These phases can happen earlier or later in the season depending on the cultivar chilling hour requirement and the weather of the location.

\section{Flowering and Fruit Growth}

This stage is probably the most critical period of the plant cycle because any water stress can reduce fruit size and yield (Berman and DeJong 1996). Flowering usually occurs in late January, and fruit growth occurs until late May (Figure 5A). As a general rule, soil water depletion should not exceed $25 \%$ of the available soil water during this period.

\section{Vegetative Growth}

During this stage (late May to late November), the tree grows new wood that will carry the next year's fruits (Figure 5B). Trees can tolerate some level of water stress during this period because there is no fruit growth. Also, excessive tree growth is unwanted because of the increased manual labor during summer pruning. Generally, for this stage, up to $50 \%$ of available soil water depletion is allowable. Because the vegetative growth stage coincides with Florida's rainy season, less irrigation is typically needed to meet water requirements during this time.

\section{Dormancy}

During these months (mid-December to early January), irrigation is less critical than during the other two stages because the trees are without leaves and growth has stopped (Figure 5C). Crop evapotranspiration is at its lowest rate and soil water depletion of more than $50 \%$ of available soil water is acceptable.

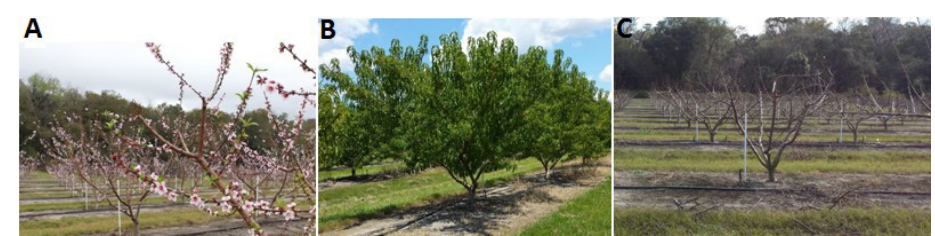

Figure 5. A) Peach trees flowering during spring; B) vegetative growth during late May-November; C) dormant trees during mid-December to early January.

Credits: Carlos Zambrano-Vaca, UF/IFAS

\section{Irrigation Scheduling Methods}

Water can be supplied to the crop based on different methods, but, depending on which one is used, the water use efficiency will change. The methods used for irrigation scheduling are:

1. Experience method ("kick the dirt"): monitoring the soil moisture directly in the orchard to decide if water is needed.

2. Systematic/schedule method: applying water every other day or on specific days of the week.

3. Soil moisture-based method: adjust irrigation based on soil water sensors (tensiometers or soil moisture sensors).

4. Weather-based method: adjust irrigation based on crop ETc.

\section{Experience Method (or "Kick the Dirt")}

This method is based solely on grower's experience to decide whether or not the orchard needs to be irrigated. The advantage of this scheduling method is that regular visits to the orchard are beneficial for monitoring other problems such as pests, fertilization, or general cultural practices that the orchard needs. The disadvantages of this scheduling method are the lack of precision and the amount of time this activity consumes.

\section{Systematic/Schedule Method}

The second method is generally implemented with an automatic timer or by hand, which initiates irrigation on specific days and times with little to no account for daily changes in rainfall or crop water demand. This scheduling method is adjusted depending on the season by increasing irrigation frequency during fruit growth and/or reducing irrigation frequency or runtime when fruits are absent or trees are dormant. An advantage of this method is that it can be adapted based on historical data and information from previous years. A disadvantage is the higher likelihood for under- or over-irrigation.

\section{Soil Moisture-Based Method (SMB)}

This method uses soil water sensors that measure soil water potential (SWP) or volumetric water content (VWC). The SWP sensor measurement corresponds to the force (suction) that roots exert to move water from the soil to the inside the plant. The dryer the soil, the higher the suction and the energy needed by the plant to uptake water. Soil water potential meters (tensiometers) measure the force 
by which the water is held by the soil particles, usually in centibars (cbar) or kiloPascal (kpa). As a general rule for sandy soils, soil water tension readings between 0 and 5 cbar indicate that the soil is near saturation and irrigation should be discontinued. When SWP sensor readings reach 10 to 15 cbar, peach trees should be irrigated as soon as possible. Readings above 25 cbar indicate severe water stress or that tensiometers are not working properly and may need to serviced (Migliaccio et al. 2015). For more information about tensiometers use and calibration, see http://edis.ifas.ufl.edu/tr015.

Soil VWC sensors estimate the volumetric water content in the soil using different principles. For more detailed information on soil moisture sensors and their advantages and disadvantages, refer to Muñoz-Carpena (2004). The VWC can be converted to soil water depth (volume of water in soil down to a given depth over a unit surface area [inches of water]) so it can be compared with ETc and rainfall. Proper use of soil moisture sensors requires knowledge of the soil water holding capacity, specifically soil moisture levels of "soil field capacity" and "wilting point". Soil field capacity is the upper limit of available soil water that remains after drainage due to the effects of gravity. Generally, for sandy soils, the VWC of soil field capacity is around 12 to $16 \%$ of VWC or (equivalent to 0.12 to 0.16 $i^{3}$ of water per in ${ }^{3}$ of soil). The wilting point is the driest condition at which plants can extract water from the soil. In sandy soils, the wilting point ranges from 5 to $7 \%$ of VWC (Zotarelli et al. 2016). For example, if the field capacity of a sandy soil is $12 \%$ and the wilting point is $5 \%$, the total soil available water range is $7 \%$. As mentioned in the section above, the irrigation scheduling of peaches during flowering and fruit growth should never exceed 25\% depletion of available soil water. In other words, when the soil moisture sensor reading reaches $10.25 \%$ of VWC (equivalent to $25 \%$ of the depletion of available soil water), irrigation should be resumed.

An example of the use of soil VWC sensors is given in Figure 6. It shows the soil VWC for different soil depths for a period of 6 days. The spikes of soil VWC are due to irrigation events on 12/12/16,12/14/16, and 12/16/16. The estimated soil field capacity is about $15 \%$. Note that irrigation events were initiated when the soil VWC sensor installed at 4 and 8 inches depth estimated 13\% VWC. In this case, the soil water depletion between irrigation intervals was about $13 \%$ (e.g., irrigation started when soil VWC was $2 \%$ below the soil field capacity). This example illustrates a proper irrigation scheduling when peach trees are in the flowering and fruit stage. Note that after the irrigation event, there are minimal changes in the soil moisture at the deeper soil levels (32 and 60 inches depth). That is a good indicator that excess irrigation water application is not occurring. An advantage of the SMB method is that readings are real-time measurements of soil water conditions and irrigation can be controlled in real time using remote connection. The disadvantage of this method is the cost of the sensors, the maintenance, and additional costs due to remote communication (service bills).

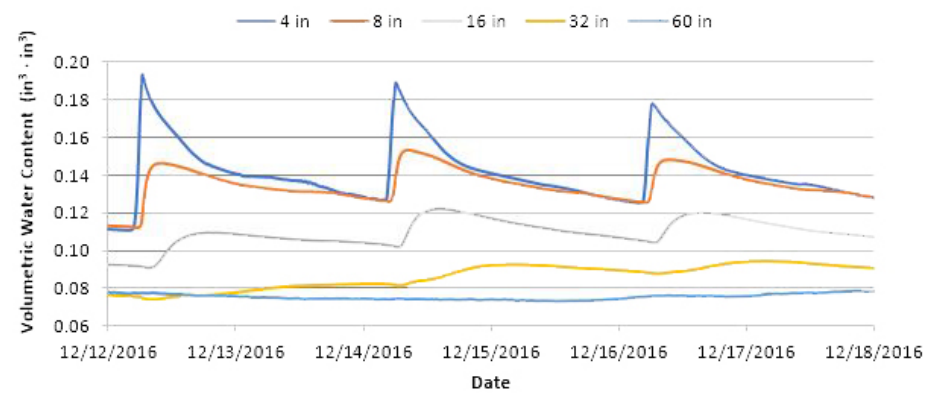

Figure 6. Soil water content at 4, 8, 16, 32, and 60 inches depth in sandy soils (Arredondo sand) from 12 to 18 December 2016, Citra, Florida.

Operation ranges of tensiometers and soil volumetric water content are provided in Table 1 as a general guide for irrigation management for peaches in sandy soils. Irrigation should be applied when readings are out of these ranges.

Table 1. Operation range of tensiometers and volumetric water content in sandy soils.

\begin{tabular}{|l|c|c|}
\hline \multicolumn{1}{|c|}{ Phenological stage } & \multicolumn{2}{c|}{ Operation range* } \\
\cline { 2 - 3 } & $\begin{array}{c}\text { Tensiometer } \\
\text { (cbar) }\end{array}$ & $\begin{array}{c}\text { VWC } \\
\left(\mathbf{i n}^{3} / \mathbf{i n}^{3} \text { ) }\right.\end{array}$ \\
\hline Flowering and fruit production & $5-10$ & $11-9$ \\
\hline Vegetative growth & $10-15$ & $9-6$ \\
\hline Dormancy & $15-20$ & $6-4$ \\
\hline *11 $\mathrm{in}^{3} / \mathrm{in}^{3}$ field capacity assumed as an example for sandy soils. \\
\hline
\end{tabular}

\section{Weather-Based Method}

The fourth method of irrigation uses ETo values generated from public sources such as FAWN (Florida Automated Weather Network) (https://fawn.ifas.ufl.edu/) or private on-site weather stations. These methods estimate the ETc losses and rainfall contributions to determine an irrigation amount (Kisekka et al. 2016).

The weather- or ET-based approach can be applied by using available resources free of charge. Methods for completing these calculations are provided by Kisekka et al. (2016). Additionally, a step-by-step ETo calculation (Zotarelli et al. 2015) can be found here: http://edis.ifas.ufl.edu/ae459. An advantage of this method is that it is free and does not require the purchase of any equipment. The disadvantage 
is that the user will need to collect appropriate information and perform the necessary calculations.

Alternatively, weather- or ET-based controllers could be used. These controllers usually collect daily information of effective rainfall, net irrigation, soil moisture, and crop evapotranspiration. The controllers use the data and the desired percentage of water depletion to irrigate only when necessary. An advantage of these controllers is that no supervision is needed, just periodical maintenance for the equipment is required. A disadvantage of this equipment is the initial investment cost and the routine maintenance bills (Dukes et al. 2015). Additional information about ET controllers can be found here: http://edis.ifas.ufl.edu/ae446.

ETo values are commonly used together with crop coefficient $(\mathrm{Kc})$ values which more accurately defines the amount of water that should be applied. Currently there are no Kc values for peaches in Florida however, Kc values from FAO-56 (Allen et al. 1998) recommendations that can help to estimate the ETc for peach production in Florida.

\section{Freeze Protection}

Freeze protection may be needed depending in which part of the state the orchard is located. One of the most common ways to freeze-protect the crop is by using irrigation water (sprinkler irrigation). Temperatures of $24^{\circ} \mathrm{F}$ at the full bloom stage can result in about $90 \%$ of buds and flowers being killed after 30 minutes of exposure (Ballard and Proebsting 1978). The lower the temperature and the longer the exposure, the more damage to flowers and buds will occur. Therefore, freeze protection is needed to prevent these damages. The principle behind the use of overhead irrigation freeze protection is that heat lost from the trees is replaced by heat released as water turns to ice. As long as water is applied constantly at enough rates and is freezing, plant temperature will remain near or at $32^{\circ} \mathrm{F}$ (Olmstead et al. 2013). More specific information about flow rates recommended and economic considerations regarding freeze protection practices information can be accessed at http://edis.ifas.ufl.edu/fe980 (Bradley et al. 2016) and http:// edis.ifas.ufl.edu/hs348 (Olmstead et al. 2013).

\section{Summary}

Proper irrigation management for peach production ensures trees are not under water stress conditions, reducing the risk of low yields and low-quality fruit. Micro-sprinkler irrigation in Florida is the preferred method used for irrigation and fertigation in peaches because micro-sprinklers can also be used for freeze protection. Determining the accurate water requirement for peaches considering the location and crop stage can improve irrigation water use efficiency and avoid low-quality fruits, low yields, and nutrient leaching. Irrigation for peaches can be divided into three seasons: flowering and fruit production, vegetative growth, and dormancy. According to these three stages, different levels of water depletion can be allowed or managed. The use of soil water sensors and historical information can improve and facilitate irrigation management of peach orchards.

\section{References}

Allen, R.G., L.S. Pereira, D. Raes, and M. Smith. 1998. "Crop evapotranspiration: guidelines for computing crop water requirements." Irrigation and Drainage Paper No. 56. Rome, Italy: Food and Agriculture Organization of the United Nations.

Ballard, J.K., and E.L. Proebsting. 1978. "Frost and frost control in Washington orchards." Bulletin No. 634. Pullman, WA: Washington State Cooperative Extension.

Bradley, T., T. Borisova, and M. Olmstead. 2016. Frost protection irrigation for florida peaches: economic considerations. FE980. Gainesville: University of Florida Institute of Food and Agricultural Sciences. http://edis.ifas.ufl.edu/ fe980

Chalmers, D.J. and I.B. Wilson. 1978. "Productivity of peach trees: Tree growth and water stress in relation to fruit growth and assimilate demand." Ann. Bot. 42:285-294.

Dukes M.D., M.L. Shedd, and S.L. Davis. 2015. Smart irrigation controllers: operation of evapotranspiration-based controllers. AE446. Gainesville: University of Florida Institute of Food and Agricultural Sciences. http://edis.ifas. ufl.edu/ae446

University of Florida. "Florida Automated Weather Network.” 27 April 2017. https://fawn.ifas.ufl.edu

Haman, D.Z., A.G. Smajstrla, and D.J. Pitts. 2005. Efficiencies of irrigation systems used in Florida nurseries. BUL312. Gainesville: University of Florida Institute of Food and Agricultural Sciences. http://itc.tamu.edu/AE08700.pdf 
Kisekka, I., K.W. Migliaccio, M.D. Dukes, B. Schaffer, J.H. Crane, and K. Morgan. 2016. Evapotranspiration-based irrigation for agriculture: sources of evapotranspiration data for irrigation scheduling in Florida. AE455. Gainesville: University of Florida Institute of Food and Agricultural Sciences. http://edis.ifas.ufl.edu/ae455

Migliaccio K.W., T. Olczyk, Y. Li, R. Muñoz-Carpena, and T. Dispenza. 2015. Using tensiometers for vegetable irrigation scheduling in Miami-Dade County. ABE326. Gainesville: University of Florida Institute of Food and Agricultural Sciences. http://edis.ifas.ufl.edu/tr015

Olmstead, M., J. Chaparro, J.G. Williamson, R. Rouse, R. Mizell, P. Harmon, and J. Ferguson. 2013. Florida subtropical peaches: Production practices. HS1109. Gainesville: University of Florida Institute of Food and Agricultural Sciences. 14 April 2017. http://ufdcimages.uflib.ufl.edu/ IR/00/00/27/44/00001/HS34800.pdf

Olmstead, M., J. Chaparro, P. Andersen, J.G. Williamson, and J. Ferguson. 2016. Florida peach and nectarine varieties. CIR1159. Gainesville: University of Florida Institute of Food and Agricultural Sciences. http://edis.ifas.ufl.edu/ mg374

Southeast Climate Consortium. 2017. "Agroclimate." 27 April 2017. http://agroclimate.org

Zotarelli L., M.D. Dukes, C.C. Romero, K.W. Migliaccio, and K.T. Morgan. 2015. Step by step calculation of the Penman-Monteith evapotranspiration (FAO-56 Method). AE549. Gainesville: University of Florida Institute of Food and Agricultural Sciences. http://edis.ifas.ufl.edu/ae459.

Zotarelli L., M.D. Dukes, and K.T. Morgan. 2016. Interpretation of soil moisture content to determine soil field capacity and avoid over-irrigating sandy soils using soil moisture sensors. AE460. Gainesville: University of Florida Institute of Food and Agricultural Sciences. http://edis.ifas.ufl.edu/ ae 460 